\title{
UNDERSTANDING DIVERSITY IN THE MEANING OF COHABITATION
}

\section{ACROSS EUROPE}

\section{Nicole Hiekel ${ }^{1}$, Aart C. Liefbroer ${ }^{2}$, Anne-Rigt Poortman ${ }^{3}$}

${ }^{1}$ Netherlands Interdisciplinary Demographic Institute (NIDI), University of Groningen (RUG) Lange Houtstraat 19, $2518 \mathrm{CV}$, The Hague, the Netherlands

${ }^{2}$ Netherlands Interdisciplinary Demographic Institute (NIDI), University of Groningen (RUG) Lange Houtstraat 19, 2518 CV, The Hague, the Netherlands Department of Sociology, VU University Amsterdam, the Netherlands De Boelelaan 1081, 1081 HV Amsterdam, the Netherlands

${ }^{3}$ Department of Sociology, Utrecht University, the Netherlands Padualaan 14, 3584 CH Utrecht, the Netherlands

Corresponding author:

Nicole Hiekel

Telephone: $+31(0) 703565236$

Fax: +31 (0)70 3647187

E-mail: hiekel@nidi.nl 


\title{
UNDERSTANDING DIVERSITY IN THE MEANING OF COHABITATION
}

\section{ACROSS EUROPE}

\begin{abstract}
This study investigates the diversity in the meanings attached to cohabitation across Europe. Utilizing a sample of 9,113 cohabiters between ages 18 and 79 from ten European countries that participated in the Generations and Gender Surveys, we develop a typology of different meanings of cohabitation and study their prevalence across and within countries. Based on answers to questions about marriage intentions, marriage attitudes and feelings of economic deprivation, six types of cohabiters are distinguished. Cohabiters in some of these types mainly view cohabitation as a stage in the marriage process (i.e., a prelude to marriage, a trial marriage, cohabitation for economic reasons, intend to marry despite an unfavourable attitude towards the institution of marriage), whereas other cohabiters mainly view it as an alternative to marriage (i.e., refusal of marriage, marriage is irrelevant). Results suggest that cohabiters constitute a heterogeneous group. For many, marriage is important and cohabitation serves as a period preceding marriage. Cohabitation as an alternative to marriage is more prevalent in Western and Northern Europe where cohabitation rates are high. The group of cohabiters who intend to marry despite an unfavourable attitude towards the institution of marriage is particularly large in Central and Eastern European countries, where cohabitation is less widespread.
\end{abstract}

Keywords:

Cohabitation, cross-national comparison, Generations and Gender Surveys, Central and Eastern Europe 


\section{INTRODUCTION}

In the last decades, unmarried cohabitation has become increasingly popular. Nowadays, most people cohabit unmarried at some point in their lives. This has led to a burgeoning of studies that compare cohabiters with their married or single counterparts (Brines and Joyner 1999; Brown and Booth 1996; Rindfuss and Vandenheuvel 1990; Soons and Kalmijn 2009; Prinz 1995). Among cohabiters, large differences may exist in the meaning that they attach to their relationship. An important academic debate circles around the question whether cohabitation serves as a prelude or an alternative to marriage (Casper and Bianchi 2002; Heuveline and Timberlake 2004; Manning and Smock 2002; Stanley et al. 2004; Willoughby et al. 2012). The former view on cohabitation implies that marriage is still central to people's lives, whereas the latter view suggests that cohabitation is increasingly substituting for marriage. In this study, we focus on the potential heterogeneity within the group of cohabiters. We argue that more knowledge about the views of cohabiters towards their living arrangement will increase our understanding of the role of cohabitation in an individual's union career and how it relates to marriage. Therefore, our first research question is: Which different meanings of cohabitation can we identify and quantify across Europe?

In studying the heterogeneity of cohabitation, it is especially important to take a comparative perspective because European countries vary in the prevalence, timing, duration and stability of cohabitation (Liefbroer and Dourleijn 2006; Kasearu and Kutsar 2011; Kalmijn 2011). Historically, in some countries, it were predominantly the poor who cohabited, whereas in other countries, cohabitation was especially common among the divorced and among those who were ideologically opposed to marriage (Trost 1978; Abrams 1993; Villeneuve-Gokalp 1991; Manting 1996). More recent studies focused on the identification of differences across countries 
in the dominant meaning of cohabitation (Heuveline and Timberlake 2004; Kiernan 2001). Studying this diversity across Europe as well as within countries will lead to a better understanding of cross-national differences in findings on cohabitation. Our second research question is therefore: How do countries differ in the prevalence of different meanings of cohabitation?

We use data from the Generations and Gender Surveys (GGS) conducted between 2004 and 2009 on nationally representative samples in ten European countries (Austria, Bulgaria, France, Georgia, Germany, Hungary, Lithuania, Norway, Romania and Russia). In Section 2 of this study the relevant literature on the meaning of cohabitation is reviewed and how this study builds on previous work. In Section 3, cross-national differences in the meanings of cohabitation are discussed and how social norms influence cohabiters in their view their unions. Section 4 introduces the data that are used. In Section 5, the indicators used to derive different types of cohabitation are presented. In Section 6, the distributions of different meanings of cohabitation are compared cross-nationally and in Section 7, the main results of this study are discussed.

\section{GRASPING THE MEANING OF COHABITATION}

The spread of unmarried cohabitation is one of the significant changes in demographic behaviour in contemporary Europe (Sobotka and Toulemon 2008). Increasingly, unions start by cohabitation rather than marriage (Billari and Liefbroer 2010) and cohabitation enters spheres that used to be exclusively reserved for marriage, most notably childbearing (Kiernan 2004; Perelli-Harris et al. 2010; Manting 1996). Several typologies of the different meanings of cohabitation have been suggested. Bianchi and Casper (2000) distinguished four cohabitation types in the United States, based on cohabiters' plans to marry and their anticipated union 
duration. Willoughby et al. (2012) identified five types of cohabiters in a non-representative sample of US-cohabiters based on their engagement status and the expected duration until marriage. Kiernan (2001) has advocated the idea that the societal diffusion of cohabitation implies a progression through four stages. Cohabitation starts as a deviant behaviour, becomes acceptable as a period preceding marriage, then becomes an alternative to marriage and finally replaces marriage or at least becomes a "type of marriage" (Prinz 1995). In its final stage, cohabitation is the norm of union entry, cohabiting unions are stable and very similar to marriage while marriage and childbearing are largely decoupled (van de Kaa 2001). The same diffusion model underlies the typology proposed by Heuveline and Timberlake (2004) who took a crossnational perspective and distinguished six meanings of cohabitation by further differentiating Kiernan's prelude to marriage-stage according to the timing of marriage (before or after childbirth). They moreover included "cohabitation as an alternative to singlehood" in their classification and thereby follow Rindfuss and Vandenheuvel (1990) who, when discussing the US context, suggested that cohabitation might share many similarities with singlehood because the partners' commitment to permanency might not be relevant during the gradual process of moving in together. The existing country-comparative typologies characterize countries by one specific meaning of cohabitation depending upon the stage of the country in the diffusion process of cohabitation.

In this paper, we propose an alternative approach to classify cohabiters that is based on two main considerations. First, we develop a classification that allows us to identify the prevalence of different meanings of cohabitation across countries, but also to study the heterogeneity of cohabitation within a country. Second, we use a subjective approach by classifying cohabiters into different types of cohabitation based on their responses to questions 
about their marriage intentions and marriage attitudes as well as subjective feelings of economic deprivation to derive a relatively parsimonious set of ideal types of cohabitation that capture how cohabiters currently view their union. We distinguish five ideal types of cohabitation. We start from two broad views on cohabitation in the literature: cohabitation as a stage in the marriage process and as an alternative to marriage.

\subsection{COHABITATION AS A STAGE IN THE MARRIAGE PROCESS}

In this view, marriage remains a valued institution and cohabitation constitutes a stage preceding marriage and may take three forms. First, cohabitation can be a form of engagement or the last phase of courtship, and thus a prelude to marriage in which couples anticipate to marry their partner, often having firm intentions to marry (Bianchi and Casper 2000; Brown 2003; Brown and Booth 1996).

Second, cohabitation might be a testing ground for marriage and thus a trial marriage that responds to uncertainties whether the dating partner is a suitable potential spouse (Seltzer 2004; Klijzing 1992). Cohabitation offers the advantages of co-residence with an intimate partner, without having to commit as yet to expected marital roles (Clarkberg et al. 1995). Existent typologies did either not distinguish between cohabitation as a prelude to marriage and a trial marriage, used either the one or the other label for a similar type of cohabitation or did not clearly state the difference in the nature of both types. In our view, both groups share a positive attitude towards marriage but differ in the anticipation of marriage. Whereas the former group has already decided to get married, the latter is evaluating the relationship.

Third, it has been argued that economic considerations shape the marriage decision (Oppenheimer 1988; Hoem 1986; Bernhardt and Hoem 1985; Kravdal 1999) and cohabitation 
might serve as a second best option when marriage is not (yet) feasible. Individuals with few economic resources are more likely to cohabit (Kalmijn 2011; Kravdal 1999; Manning and Smock 2002). Some might not be able to afford the costs for the wedding (Kravdal 1997), whereas others might not feel sufficiently economically consolidated to warrant the step to marriage with its inherent role expectations and the mutual claim on each other's property (Clarkberg 1999; Oppenheimer 1988, 2003). For instance, being enrolled in education is perceived as incompatible with the role of a spouse (Blossfeld and Huinink 1991). In addition, marriage is often associated with having children - an expensive undertaking for which financial means need to be accumulated first (Clarkberg et al. 1995). According to this view, some people cohabit because of economic reasons.

\subsection{COHABITATION AS AN ALTERNATIVE TO MARRIAGE}

A contrasting view on cohabitation understands it as an alternative to marriage. It suggests that marriage is losing its dominant status and cohabitation increasingly substitutes for it. Two main reasons are mentioned in the literature. First and foremost, individuals may cohabit out of an ideological refusal of marriage. Cohabiters in this type view marriage as a bourgeois and outdated institution (Casper and Bianchi 2002), are in stable long-term relationships (Bianchi and Casper 2000), value personal autonomy and have liberal attitudes with regard to gender roles and the division of labour (Clarkberg et al. 1995).

Second, cohabiters may feel that marriage is not relevant for them. They do not reject marriage for ideological reasons; they just do not consider it important to get married. Marriage would not make any difference for their commitment and feelings towards their partner; they might even feel that they are in a way married, just not in the legal sense. This type of 
cohabitation has been described by Kiernan (2002a) who identified it as the last stage of the diffusion process of cohabitation.

\section{DIFFERENCES IN THE MEANING OF COHABITATION ACROSS EUROPE}

Previous research on the meaning of cohabitation mainly focused on Western European (Kiernan 2002a) and the EU-15 area countries (Kiernan 2002b) or compared the United States to a variety of European countries as well as Canada and New Zealand (Heuveline and Timberlake 2004). Relatively little attention has been paid to countries situated in Central and Eastern Europe that relatively recently witnessed a dramatic increase in unmarried cohabitation (Sobotka 2003). Historically, marriage patterns in Northern and Western Europe differed from other parts of Europe (Thornton 2005). Hajnal (1965) suggested a geographical division of Europe into two marriage regimes by drawing an imaginary line from St. Petersburg to Trieste. He described marriage west of the line as late and non-universal and east of the line as early and nearly universal. This divide has been endorsed by the geopolitical division of Europe by the Iron Curtain for more than four decades. Until the political transformations of the late 1980s and early 1990s, Central and Eastern Europe was largely isolated from Western and Northern Europe, where in turn dramatic changes in demographic behaviour have occurred since the late 1960s. Often, these changes have been attributed to value and attitudinal shifts (Surkyn and Lesthaeghe 2004; Thornton and Young-DeMarco 2001; van de Kaa 1987). Increasing secularization, weakening family ties, and growing individualization would have boosted the spread of cohabitation and its rising significance as an institution of family formation during the so-called second demographic transition (Lesthaeghe and van de Kaa 1986). 
It has been argued that, during the societal, political and economic transformation of the institutional structure of Central and Eastern Europe, many of the countries in that region experienced an ideational change that led to the embracement of the values, attitudes and lifestyle of the West as a synonym of "development, progress and the good life to be" (Thornton and Philipov 2009, p. 135). This transformation would have led to the "westernization of demographic patterns" in this region (Sobotka 2003, p. 476) as people had more opportunities and a greater deal of freedom in making choices over their lives.

The cultural explanation with its focus on shifts in individual preferences provides one framework to explain cross-national variation in the meanings of cohabitation. Its basic idea is that positive attitudes towards unmarried cohabitation are spreading from Northern European countries to the rest of Europe. Cross-national differences in the meaning of cohabitation are explained by countries being situated at different stages of this transition (Heuveline and Timberlake 2004; Kiernan 2001, 2002b). In Northern as well as some Western European countries, unmarried cohabitation has become the normal start of a union that largely replaced direct marriage (Billari and Liefbroer 2010). At the same time, norms to get married are low and a significant proportion of cohabiters might never marry their partner. As a consequence of Western and Northern Europe being further advanced in the societal diffusion of cohabitation than Central and Eastern Europe, certain cohabitation types may be overrepresented in Western and Northern Europe, such as viewing cohabitation as an "end in itself" rather than a stepping stone in the marriage process. In these countries, cohabiters may also constitute a more diverse group which would lead to a larger diversity of the cohabitation typology. The lower diffusion and societal approval of cohabitation in Central and Eastern Europe may lead fewer people to 
enter cohabitation and for those who happen to cohabit, it may mostly be short-lived while at the same time, diversity in the meanings of cohabitation may be low.

Cultural factors may not be the only ones to explain European differences in cohabitation patterns. It is also debated whether the rising significance of unmarried cohabitation in Central and Eastern Europe might be a consequence of increased economic uncertainty and social disintegration. The economic explanation emphasizes the constraints that individuals experience in the process of union formation. The turmoil of the fall of the Iron Curtain might have decreased individuals' confidence in making commitments to largely irreversible demographic decisions such as marriage and childbearing (Kohler et al. 2002; Philipov et al. 2006). Increased economic uncertainty may lead people to postpone marriage, particularly those who enter the labour market or are in unstable and low paid employment. Studies on union formation processes in Central and Eastern Europe have shown a positive educational gradient of entry into marriage (Bradatan and Kulcsar 2008; Kantorova 2004; Gerber and Berman 2010; Hoem and Kostova 2008) and argued that these educational differences can be attributed to economic inequality rather than ideational change. Several country-specific studies on cohabitation in this region found that cohabitation is more prevalent among the lower social strata of society (Kotycheva and Philipov 2008; Perelli-Harris et al. 2010; Potancokova et al. 2008; Spéder and Kamarás 2008) although some of these studies conclude that, for younger birth cohorts, educational differences in the choice of union type become smaller. Following the economic argument, one could explain cross-national variation in the mix of cohabitation types by economic variation across countries. If cohabitation is a consequence of economic disadvantage, we would expect to find more cohabiters in this type of cohabitation in Central and Eastern Europe than in Western and Northern Europe (Bernhardt and Hoem 1985; Hoem 1986). 
However, in a context where poverty is widespread, economic conditions may be however not that essential in how cohabiters view their unions. This may be particularly true when traditional norms about marriage have persisted and cohabitation is disapproved as a long term alternative to marriage. When social norms to marry are strong, financial obstacles might be lower, for instance because parents are willing to pay for their children's wedding or it is more common to have a less elaborate wedding festivity.

The previous argument illustrates that attaching meaning to one's cohabiting union does not happen in a social vacuum but relates to social norms about cohabitation and marriage in the social environment. The existence and influence of such group-held beliefs about appropriate behaviour can affect cohabiters' views on their union in two ways. First, social norms are internalized during the lifelong process of socialization and might thus be replicated when individual attitudes towards marriage and cohabitation are formed (Barber et al. 2002). Hence, in a context where traditional norms towards cohabitation and marriage prevail, individuals may be more likely to hold the same values. Second, individuals also respond to social norms independently of their own attitudes and thus show conformity to widely accepted behaviour in their social environment (Liefbroer et al. 1994). Social norms, transmitted through social control and pressure might lead to conformism. Thus, in contexts with strong traditional norms about union formation, people might be less likely to enter cohabitation and to proceed faster to marriage, if they happen to cohabit (Thornton et al. 2007).

\section{DATA}

We use data from the Generations and Gender Surveys on ten countries. The GGS is a set of comparative surveys of a nationally representative sample of the 18-79 year old resident 
population in each of the participating countries (Vikat et al. 2007). To date, Wave 1 data collected between 2004 and 2009 is available for 15 countries: Austria, Australia, Belgium, Bulgaria, Estonia, France, Georgia, Germany, Hungary, Italy, Lithuania, the Netherlands, Norway, Romania, and the Russian Federation. The overall sample size of the samples differs by country but in most cases is about 10,000 respondents. We had to exclude Australia, Belgium, Estonia, Italy, and the Netherlands from our analysis, as crucial variables for our analysis were not available for these countries. The age range of the Austrian sample differs from other countries because only individuals aged 18 to 45 were interviewed. The overall response rates vary between $49 \%$ in Russia and $78 \%$ in Bulgaria.

Of all respondents living with a partner $(n=70,108)$ we excluded those who are married to this partner $(n=59,630)$, those with an unknown marital status $(n=77)$, those with a partner of the same sex $(n=87)$, and those whose partners' sex was unknown $(n=4)$. As will be explained in more detail in the next section, we used three empirical indicators to distinguish different types of cohabitation, namely marital intentions, attitudes towards marriage and subjective feelings of economic deprivation. We limited our analysis to cohabiters who have valid data on these three indicators defining meaning of cohabitation. In Norway, the question on marital attitudes was part of a self-administered questionnaire that respondents were requested to return via mail and $30 \%$ did not. Overall, missing data on the explaining variables were rare $(<2 \%)$ and excluded from the analysis. Additional analyses with "missing" as an additional category led to virtually similar results as presented here (results available upon request). Our final analytical sample contains 9,113 men and women who cohabit with a partner, ranging from 449 in Romania and 1,571 in Norway. 


\section{DISTINGUISHING DIFFERENT TYPES OF COHABITATION}

In order to translate our cohabitation typology into an empirically measurable classification, we use three key indicators, namely (1) intentions to marry, (2) attitudes towards the institution of marriage and (3) subjective economic deprivation, to distinguish between types of cohabitation.

A number of previous studies have stressed the importance of marital intentions to understand cohabiters' behaviours (Manning and Smock 2002; Wiik et al. 2010; Ciabattari 2004; Guzzo 2009). Cohabiters with marital intentions have been found to be four times as likely to actually marry within three years than cohabiters without marriage plans (Manning and Smock 2002). Additionally paying attention to attitudes towards the institution of marriage is particular relevant to understand how cohabiters without clear marital intentions view their unions. As Coast (2009) noted, the absence of marital intentions can mean different things: the ideological rejection of the institution of marriage, an assessment that the current partner is not a suitable potential spouse but no opposition to marriage per se, or that the couple is not yet contemplating marriage. The attitude one holds about the institution of marriage is likely to be intertwined with how relevant it is for oneself to get married. Cohabiters who consider marriage an outdated institution might be less likely to marry than cohabiters who are in favour of the institution of marriage. Taking into account marital attitudes is not only important to further distinguish the group of cohabiters who do not intend to marry soon, but also among those who intend to marry. We argue that, given the diversity of countries that we can study here, it is particularly tempting to explore whether countries who differ in the prevalence of unmarried cohabitation also differ in the proportion of cohabiters whose plans to marry are not in line with how they view the institution of marriage. 
Intentions to get married in the near future have been measured by asking: "Do you intend to marry your partner within the next three years?" In Norway, respondents were asked for marriage plans within two years. Respondents who answered definitely yes or probably yes are considered to have marriage plans. Those who responded probably no, definitely no or does not know are treated as having no marital intentions. Norwegian respondents could only choose between yes and no. In Hungary a negative answer could only be no. Table 1 shows that between $17 \%$ of respondents in Norway and $74 \%$ in Romania report having plans to marry in the near future.

Attitudes towards marriage were measured by the level of agreement towards the statement "Marriage is an outdated institution" on a 5-point scale (1= strongly agree, $3=$ neither agree nor disagree, 5=strongly disagree). Respondents with values 1 or 2 are classified as agreeing that marriage is an outdated institution. Respondents with a value 4 or 5 are considered to disagree and respondents with a value 3 are classified as being indifferent about marriage. Agreement is particularly low in Georgia (9\%) and Romania (18\%) and highest in Bulgaria where almost half of the sample considers marriage outdated (Table 1).

Finally, how cohabiters view their union does not just depend on their preferences but also on perceived constraints. Facing a difficult economic situation might lead people to postpone any further institutionalization of their union although they aspire to marry one day. To capture subjective economic deprivation we used responses to the question: "Thinking of your household's total monthly income is your household able to make ends meet ..." The 6-point scale ranges from with great difficulty to very easily. We consider respondents who answer with (great) difficulty as feeling economically deprived. Table 1 shows that feelings of economic deprivation are more frequent in Central and Eastern Europe (with the exception of Hungary and 
Lithuania) than in Western and Northern Europe. Nevertheless, even in the latter countries, between 3\% in Norway and 25\% in France have trouble making ends meet.

[Table 1 about here]

Table 2 illustrates how we construct an empirical classification of cohabiters based on their responses to our three main indicators. Cohabiters who have marriage plans in the near future and disagree that marriage is an outdated institution are classified as viewing cohabitation as a prelude to marriage. Cohabiters who have no marital intentions in the near future and do not consider marriage outdated are grouped into a category "not ready yet". Reasons for not feeling ready yet could be related to preferences as well as to perceived constraints. Those who do not feel economically deprived are classified into the "trial marriage" type of cohabitation. Cohabiters who do feel economically deprived are classified as belonging to the group that cohabits for economic reasons. Feelings of economic deprivation are not relevant in distinguishing other types of cohabitation. Cohabiters who have no marital intentions and consider marriage an outdated institution are classified as refusing marriage. Finally, cohabiters without intentions to get married but who are indifferent about marriage are classified as considering marriage irrelevant.

[Table 2 about here]

\section{RESULTS}

We deductively defined a typology of different meanings of cohabitation and assigned each respondent to one of the types based on his or her response pattern on the key indicators distinguishing the cohabitation types. In order to answer our first research question we compare the distributions of different cohabitation types within and across ten European countries. In 
order to answer our second research question on cross-national differences in cohabitation patterns, we calculate the proportion of cohabiters among all co-resident partnerships as well as a measure of entropy (=amount of variation of the typology) for each country. We then discuss patterns and variations in the distribution of different meanings within and across countries.

Table 3 shows the percent distribution of different meanings of cohabitation for each country in our study. For the large majority of cohabiters, cohabitation is viewed as a stage in the marriage process rather than as an alternative to it. Across countries, we identify between half of the cohabiters (Norway) and virtually all cohabiters (Georgia) as being classified into one of the subclasses of cohabitation viewed as a precursor to marriage. Among those, most cohabiters have plans to get married in the near future. Cohabitation as a prelude to marriage is most prevalent in Georgia (66\%) and Romania (39\%), whereas in Western European countries, their proportion varies between $11 \%$ (Norway) and 27\% (Austria). With the exception of Hungary where $13 \%$ of cohabiters are classified as viewing their union as a trial marriage, this type of cohabitation comprises less than ten percent of all cohabiters in Eastern Europe, and is thus lower compared to cohabiters in Western Europe (15\% to $29 \%$ ). In country, at least a small group of cohabiters is classified as cohabiting for economic reasons and their proportion is largest in Russia (17\%).

The prevalence of viewing cohabitation as an alternative to marriage because one refuses the institution of marriage varies strongly across countries and is most common in Bulgaria where one third of all cohabiters are classified into this type. In Georgia and Romania by contrast, only a small minority cohabits is assigned to this group ( 2 and $5 \%$, respectively). The largest proportion of cohabiters classified as considering marriage irrelevant is found in Norway (32\%), whereas in all other countries, this proportion is maximum 18\% (Austria). 
Although the majority of respondents in all countries could be assigned to one of these five theoretically-based types, we also find a significant proportion of cohabiters who do not fit this classification, a group that is too large to form a residual category. These are respondents who feel ideologically disconnected from marriage by either agreeing that it is an outdated institution or being indifferent to it. At the same time, though, they still have plans to get married in the near future. We suggest classifying these cohabiters as "conformists". Cohabiters in this category might intend to marry in order to please their family, friends or society in general. They might also have incentives to get married. Such rational reasons might be tax benefits or legal protection of the union despite holding an unfavourable opinion about the institution of marriage. Conformism is more prevalent among cohabiters in Eastern Europe and ranges between 14\% (Georgia) and 39\% (Lithuania).

In order to put these findings into perspective, Table 3 also shows for each country the proportion of cohabiters among all individuals with a partner living in the same household. Cohabitation is marginal in Romania (5\%), followed by Bulgaria and Lithuania (11\%), Hungary and Georgia (14\%) and Russia (15\%). In Western Europe, between 12\% (Germany) and 23\% (Norway) of all co-resident partnerships are cohabitations. The high cohabitation rate in Austria $(30 \%)$ is at least partially caused by the smaller age range covered by the Austrian GGS that results in an overrepresentation of younger age groups, which are more likely to cohabit.

When relating our findings on the distribution of different types of cohabitation to the cohabitation rates on the country level, it shows that — as expected - cohabitation as a prelude to marriage is more prevalent in countries where cohabitation rates are low, such as Romania, Georgia, and Lithuania and in turn relatively rare in Norway where cohabitation is highly diffused. In Western Europe, where overall more people cohabit, more cohabiters attach other 
meanings to their unions, particularly viewing cohabitation as a trial marriage, as a refusal of marriage or considering marriage as being irrelevant. As expected, these meanings are rather uncommon in Eastern European countries, although there are exceptions. For instance, despite the rather low prevalence of cohabitation in Bulgaria, one third of the cohabiters are classified as refusing marriage. Cohabiters being classified as "conformists", hence adhering to social norms by intending to marry despite a less favourable attitude towards marriage, are more prevalent in Eastern European countries where overall cohabitation rates are low.

In Section 2, we suggested that more diversity in the meaning of cohabitation could be observed in countries that have progressed further in the diffusion of cohabitation. To examine this, we calculated a measure of entropy of the cohabitation typology (Billari 2001) ${ }^{1}$. This is a measure of variation that ranges from 0 to 1 , the latter implying maximal variation of types. In the case of high entropy, an equal number of cohabiters have been assigned to each of the different types of cohabitation. By contrast, low entropy implies that one meaning of cohabitation dominates among cohabiters in a country. In our study, the measure of variation ranges from .48 in Georgia to .75 in France and Russia. In Georgia, the entropy is lowest because virtually all cohabiters are classified as being in the prelude to marriage type. In Romania, where cohabitation rates are lowest, the entropy of the typology is rather low as well. This is because two different meanings of cohabitation are dominant, namely cohabitation as a prelude to marriage and conformism. In Hungary and Russia, the entropy is highest among countries in Eastern Europe and comparable to that in the countries of Western Europe. The different meanings of cohabitation are more equally distributed in their prevalence. The entropy is smaller

\footnotetext{
${ }^{1}$ The entropy of the cohabitation typology by country is defined as the negative sum of the proportion of cohabiters assigned to each meaning of cohabitation multiplied by its logarithm $0 \leq H c=-\sum_{i}^{k} p_{i} \log \left(p_{i)} \leq \log (k)\right.$
} 
in Norway than in Western European countries, because many cohabiters consider marriage irrelevant. Diversity in the meanings of cohabiters is thus lowest in countries where cohabitation is marginal (Romania) as well as in countries where it is strongly diffused (Norway). The heterogeneity is largest in Western European countries with medium levels of cohabitation.

[Table 3 about here]

\section{DISCUSSION}

This study aimed to increase our understanding of why people cohabit. We built a typology about the different meanings of cohabitation based on the existing literature. We used crossnational comparable data for ten European countries to examine which different types of cohabitation we can empirically distinguish.

Most cohabiters view their union as a transitory stage in the marriage process. Some of them have already firm wedding plans; others are still testing their relationship or are in the process of establishing the economic preconditions to think about marriage. These findings underscore previous work that suggests that cohabitation is not about to replace marriage for the majority of cohabiters (Billari and Liefbroer 2010; Brown and Booth 1996). Marriage remains an important institution and an aim for many cohabiters (Ni Bhrolcháin and Beaujouan 2013). The findings confirm that cohabitation nevertheless has become an increasingly normative step in the process of union formation in many countries (Liefbroer and Billari 2009). In particular in societies where marriage is no longer universal and the costs and prevalence of divorce are high, cohabitation offers the opportunity to live together with an intimate partner, experiencing and enduring the challenges of everyday life while securing a relatively easy way out if the relationship finally does not work. 
A minority of cohabiters in this study do not intend to marry, are positive about the institution of marriage and report trouble making ends meet. Facing economic hardship seems to induce cohabiters to think that they are not yet ready to commit to marriage. Following earlier work by Bernhardt and Hoem (1985), we argue that the popular assumption that cohabitation emerged mainly as an elite phenomenon of highly educated individualists might actually not be the whole story. People also settle for cohabitation as a second best option when they do not yet have accomplished preconditions for marriage that are related to employment, career goals and material wealth (Kravdal 1999; Kalmijn 2011). In some Eastern European countries, more than half of all cohabiters report have trouble to make ends meet (Bulgaria, Georgia, Romania, Russia). This finding is not surprising as poverty in the post-communist countries is endemic among larger parts of the population and not limited to cohabiters. Though many respondents report having difficulties to make ends meet, the proportion who is classified as being cohabiting for economic reasons is relatively low, though higher than in Western Europe. Our interpretation is that in a less prosperous country in which traditional norms towards marriage prevail, economic preconditions of marriage might not be that central in how cohabiters view their union. In prosperous countries, the social expectations about the event of the wedding are argued to be high, which increases the financial costs associated with a wedding. Particularly cohabiters who lack economic security would therefore postpone marriage (Kravdal 1999; Wiik 2009; Blossfeld and Huinink 1991; Kohler et al. 2002). Our finding that only a minority of Western European cohabiters are classified as cohabiting for economic reasons thus should certainly not be interpreted as if economic constraints would be irrelevant for understanding the diversity of cohabitation. We could imagine that economic preconditions to marry might be more difficult to grasp in Western Europe, even with subjective measurements of economic prosperity. 
Economic deprivation is a multidimensional phenomenon and challenging to measure appropriately with the instruments usually available in survey data. It could be that some cohabiters in Western Europe who are classified as being in a trial marriage, might postpone marriage for economic reasons, although they do not report having trouble to make ends meet. For instance, cohabiters who do not consider themselves economically deprived may still have to decide whether to spend their assets on a fancy wedding party or to pay the mortgage for a house - plans that time wise might coincide.

We identify two groups of cohabiters who might never marry their partner. Some of them consider the institution of marriage an outdated institution and report no plans to marry in the near future. Others do not intend to marry either, but at the same time do not have a strong opinion about marriage. For these cohabiters it is very likely that cohabitation replaces marriage as a long term living arrangement. Not the marital status, but the fact of coresidence defines them as a long term, committed couple relationship. Viewing cohabitation as an alternative to marriage is more widespread in Western Europe. Sociologists have posited an individualization of intimate relationships occurring in contemporary Western societies in which partners value individual autonomy and self-realization. In order to maintain individual autonomy and the ease of leaving a union that is no longer considered self-fulfilling, Western Europeans might be more likely to cohabit and view it as a rejection of traditional marriage. At the same time, many Western European countries have experienced a blurring of the differences between the legal responsibilities, rights and social expectations of marriage and cohabitation (Perelli-Harris and Sánchez Gassen 2012). This might have eased the emergence of cohabitation as an alternative to marriage in which people build up long term commitment and form families without viewing a need to have a marriage license. A similar argument has been brought forward by previous 
typologies that have placed cohabitation as an alternative to marriage at later stages of the diffusion process of cohabitation (Kiernan 2001; Heuveline and Timberlake 2004). Other scholars, by contrary, have described the ideological opposition to marriage as the motivation of the avant-garde to practice cohabitation, for instance in the Netherlands (Manting 1996). Hence, this view on cohabitation would be also found at early stages of the diffusion of cohabitation. Our study of within- country diversity in the meanings of cohabitation revealed that indeed, ideologically motivated cohabitation can be found in countries where cohabitation is marginal, though less than in high cohabitation countries. The high proportion of cohabiters in Bulgaria who ideologically refuse marriage despite that less than 11 percent of co-resident unions are cohabitations, is an exception and has been previously mentioned in the literature (Hoem and Kostova 2008).

Another central result of this study is that we identify a sixth type of cohabitation that has so far not been discussed in the literature. A considerably large group of cohabiters plan to marry although they consider marriage an outdated institution or do not have a strong opinion about marriage. We termed this group as "conformists". This group is particularly large in some countries of Central and Eastern Europe. This finding clearly shows that the fact that marriage is a prominent social institution that still strongly influences how cohabiters think about their unions, even those who are not in favour of marriage. As a result, some cohabiters plan to marry by conforming to social norms despite having a less favourable personal opinion about the institution of marriage. In addition, the result suggests that rational considerations such as the legal recognition of the union or the protection of children, property or inheritance might play an important role in the decision to marry (Perelli-Harris et al. 2012). 
Three promising avenues for future research could be suggested. First, it is important to realize that we inferred the meaning of cohabitation from response patterns on key indicators that are suggested to define different types of cohabitation. Ideally, comparative surveys should include questions in which cohabiters are explicitly asked why they live together unmarried, thus providing us with a more direct measure of the meaning of cohabitation. In the absence of such data, we opted for a relatively parsimonious set of ideal types of cohabitation, as any typology has to strike a balance between simplicity and complexity. Though such an approach runs the risk of losing some nuances in the meanings of cohabitation, we believe that constructing a typology based on the combination of marital intentions and attitudes constitutes an innovative contribution to understand the different meanings of cohabitation. Someone who does not report any plans to marry but who is generally positive about the institution of marriage might marry one day but (for all kinds of possible reasons) not now. If someone intends to marry but is not that positive about marriage, we assume that his or her intention to marry stems from other than ideological reasons and might reflect the perceived absence of alternatives. Also with regard to one's attitudes toward the institution of marriage, the combination with marital intentions allows us to get further insights into the meaning of cohabitation: Being positive about marriage in general does not necessarily imply that one wants to marry oneself. Also empirically, the combination of marital intentions and attitudes adds to our understanding of the heterogeneous nature of cohabitation, even over and above just examining marital intentions. Future research may reveal marked differences in both in the characteristics of individuals being classified into each of the cohabitation types (i.e., their educational attainment, age, parental status) as well as the behaviour between groups of cohabiters that would remain hidden if the indicators would be examined separately, for instance by studying the transition to marriage. 
Second, using cross-sectional data, our typology is a snapshot of the current meaning that cohabiters attach to their relationship. Cohabiters who are very much oriented towards marriage might quickly transform their union into a marriage and consequently, might be underrepresented in our analytical sample. The meaning of cohabitation can moreover change over the course of a relationship. Cohabitation should thus be conceptualized as a process rather than an event (Kiernan 2001). Many of the "long term cohabitations" in which partners are highly committed to each other might have started as "provisional cohabitations" (Théry 1998) characterized by a lack of commitment and low exit costs where partners have little sense of common property (Martin and Théry 2001). Individual longitudinal data on cohabitation —and on its meaning — would enable us to study both the current and lifetime experience of cohabitation (Seltzer 2004).

Finally, it was beyond the scope of this paper to examine to which extent cohabiters' views on cohabitation might differ compared to how married or single individuals view cohabitation and marriage. We could imagine that cohabiters who are classified as viewing their union as a prelude to marriage are more similar to married respondents in their views on cohabitation than other types of cohabiters. Prior studies for instance have shown that cohabiting unions in which marital intentions are present are not qualitatively different from married unions (Brown and Booth 1996; Wiik et al. 2009). We could also imagine that countries may differ in the extent to which the views on cohabitation and marriage differ by relationship status. It is well established that selection into cohabitation is stronger in contexts in which cohabitation is marginal. In such countries, cohabiters constitute a very selective subpopulation and might hold very different attitudes towards marriage and cohabitation than people in other union types. By contrast, in countries where cohabitation has become the normative start of a union, many 
married respondent have cohabited before they got married and never married people plan may start a future union by cohabitation. Future cross-national survey data that combines information on union formation attitudes and behaviour could shed more light on these issues. 


\section{REFERENCES}

Abrams, L. (1993). Concubinage, cohabitation and the law: Class and gender relations in nineteenth-century Germany. Gender and History, 5, 81-100.

Barber, J. S., Axinn, W. G., \& Thornton, A. (2002). The influence of attitudes on family formation processes. In R. Lesthaeghe (Ed.), Meaning and choice: Value orientations and life course decisions. The Hague: Netherlands Interdisciplinary Demographic Institute.

Bernhardt, E., \& Hoem, B. (1985). Cohabitation and social background: Trends observed for Swedish women born between 1936 and 1960. European Journal of Population, 1, 375395, doi:10.1007/BF01797149.

Bianchi, S. M., \& Casper, L. M. (2000). American families. Population Bulletin, 55, 3-42.

Billari, F. C. (2001). The analysis of early life courses: complex descriptions of the transition to adulthood. Journal of Population Research, 18(2), 119-142, doi:10.1007/BF03031885.

Billari, F. C., \& Liefbroer, A. C. (2010). Towards a new pattern of transition to adulthood? Advances in Life Course Research, 15(2-3), 59-75, doi:10.1016/j.alcr.2010.10.003.

Blossfeld, H.-P., \& Huinink, J. (1991). Human capital investments or norms of role transition? How women's schooling and career affect the process of family-formation. American Journal of Sociology, 97, 143-168, doi:10.1086/229743.

Bradatan, C., \& Kulcsar, L. (2008). Choosing between marriage and cohabitation: Women's first union patterns in Hungary. Journal of Comparative Family Studies, 39(4), 491-507.

Brines, J., \& Joyner, K. (1999). The ties that bind: Principles of cohesion in cohabitation and marriage. American Sociological Review, 64(3), 333-355, doi:10.2307/2657490.

Brown, S. L. (2003). Relationship quality dynamics of cohabiting unions. Journal of Family Issues, 24(5), 583-601, doi:10.1177/0192513X03252671.

Brown, S. L., \& Booth, A. (1996). Cohabitation versus marriage: A comparison of relationship quality. Journal of Marriage and the Family, 58(3), 668-678, doi:10.2307/353727.

Casper, L. M., \& Bianchi, S. M. (2002). Continuity and change in the American family. Thousand Oaks, CA: Sage Publications.

Ciabattari, T. (2004). Cohabitation and housework: The effects of marital intentions. Journal of Marriage and Family, 66(1), 118-125, doi:10.1111/j.0022-2445.2004.00009.x.

Clarkberg, M. (1999). The price of partnering: The role of economic well-being in young adult's first union experiences. Social Forces, 77(3), 945-968, doi:10.1093/sf/77.3.945.

Clarkberg, M., Stolzenberg, R. M., \& Waite, L. J. (1995). Attitudes, values, and entrance into cohabitational versus marital unions. Social Forces, 74(2), 609-632, doi:10.2307/2580494.

Coast, E. (2009). Currently cohabiting: Relationship attitudes, expectations and outcomes. In J. Stillwell, E. Coast, \& D. Kneale (Eds.), Fertility, living arrangements, care and mobility: understanding population trends and processes. Dordrecht: Springer.

Gerber, T. P., \& Berman, D. (2010). Entry to marriage and cohabitation in Russia, 1985-2000: Trends, correlates, and implications for the Second Demographic Transition. European Journal of Population, 26(1), 3-31, doi:10.1007/s10680-009-9196-8. 
Guzzo, K. B. (2009). Marital intentions and the stability of first cohabitations. Journal of Family Issues, 30, 179-205.

Hajnal, J. (1965). European marriage pattern in historical perspective. In D. V. Glass, \& D. E. C. Eversley (Eds.), Population in History. London: Arnold.

Heuveline, P., \& Timberlake, J. M. (2004). The role of cohabitation in family formation: The United States in comparative perspective. Journal of Marriage and the Family, 67(2), 1214-1230, doi:10.1111/j.0022-2445.2004.00088.x.

Hoem, J. M. (1986). The impact of education on modern family-union initiation. European Journal of Population, 2(2), 113-133, doi:10.1007/BF01796886.

Hoem, J. M., \& Kostova, D. (2008). Early traces of the Second Demographic Transition in Bulgaria: A joint analysis of marital and non-marital union formation, 1960-2004. Population Studies, 62(3), 259-271.

Kalmijn, M. (2011). The influence of men's income and employment on marriage and cohabitation: Testing Oppenheimer's theory in Europe. European Journal of Population, 27(3), 269-293, doi:10.1007/s10680-011-9238-x.

Kantorova, V. (2004). Education and entry into motherhood: The Czech Republic during state socialism and the transition period (1970-1997). Demographic Research, Special Collection 3(10), 245-274, doi:10.4054/DemRes.2004.S3.10.

Kasearu, K., \& Kutsar, D. (2011). Patterns behind unmarried cohabitation trends in Europe. European Societies, 13(2), 307-325, doi:10.1080/14616696.2010.493586.

Kiernan, K. (2001). The rise of cohabitation and childbearing outside marriage in western Europe International Journal of Law, Policy and the Family, 15, 1-21, doi:10.1093/lawfam/15.1.1.

Kiernan, K. (2002a). Cohabitation in Western Europe. Trends, issues, and implications. In A. Booth, \& A. C. Crouter (Eds.), Just living together. Implications of Cohabitation on Families, Children, and Social Policy (pp. 3-31): Lawrence Erlbaum Associates, Inc.

Kiernan, K. (2002b). The state of European unions: An analysis of partnership formation and dissolution. In M. Macura, \& G. Beets (Eds.), Dynamics of fertility and partnership in Europe: insights and lessons from comparative research (Vol. 1, pp. 57-76). UN New York and Geneva.

Kiernan, K. (2004). Unmarried cohabitation and parenthood in Britain and Europe. Law and Policy, 26(1), 33-55, doi:10.1111/j.0265-8240.2004.00162.x.

Klijzing, E. (1992). 'Weeding' in the Netherlands: First union disruption among men and women born between 1928 and 1965. European Sociological Review, 8(1), 53-70.

Kohler, H.-P., Billari, F. C., \& Ortega, J. A. (2002). The emergence of lowest-low fertility in Europe during the 1990s. Population and Development Review, 28(4), 641-680, doi:10.1111/j.1728-4457.2002.00641.x.

Kotycheva, E., \& Philipov, D. (2008). Bulgaria: Ethnic differentials in rapidly declining fertility. Demographic Research, 19(13), 361-402, doi:10.4054/DemRes.2008.19.13

Kravdal, O. (1997). Wanting a child without a firm commitment to the partner: Interpreations and implications of a common behaviour pattern among Norwegian cohabitants. European Journal of Population, 13, 269-298, doi:10.1023/A:1005943724645.

Kravdal, O. (1999). Does marriage require a stronger economic underpinning than informal cohabitation? Population Studies, 53(1), 63-80, doi:10.1080/00324720308067. 
Lesthaeghe, R., \& van de Kaa, D. J. (1986). Twee demografische transities? (Two demographic transitions?). In D. J. Van de Kaa, \& R. Lesthaeghe (Eds.), Bevolking: Groei en Krimp (Population: Growth and Decline) (pp. 9-24). Deventer: Van Loghum Slaterus.

Liefbroer, A. C., \& Billari, F. C. (2009). Bringing norms back in: A theoretical and empirical discussion of their importance for understanding demographic behaviour. Population, Space and Place, 16, 287-305.

Liefbroer, A. C., \& Dourleijn, E. (2006). Unmarried cohabitation and union stability: Testing the role of diffusion using data from 16 European Countries. Demography, 43(2), 203-221, doi:10.1353/dem.2006.0018.

Liefbroer, A. C., Gerritsen, L., \& De Jong Gierveld, J. (1994). The influence of intentions and life course factors on union formation behavior of young adults. Journal of Marriage and Family, 56(1), 193-203, doi:10.2307/352713.

Manning, W. D., \& Smock, P. J. (2002). First comes cohabitation and then comes marriage? A research note. Journal of Family Issues, 23(8), 1065-1087, doi:10.1177/019251302237303.

Manting, D. (1996). The changing meaning of cohabitation and marriage. European Sociological Review, 12(1), 53-65, doi:10.1093/oxfordjournals.esr.a018177.

Martin, C., \& Théry, I. (2001). The PACS and marriage and cohabitation in France. International Journal of Law, Policy and the Family, 15, 135-158, doi:10.1093/lawfam/15.1.135.

Ni Bhrolcháin, M., \& Beaujouan, E. (2013). Education and cohabitation in Britain: A return to traditional patterns? Population and Development Review, 39(3), 441-458.

Oppenheimer, V. K. (1988). A theory of marriage timing. American Journal of Sociology, 94(3), 563-591, doi:10.1086/229030.

Oppenheimer, V. K. (2003). Cohabiting and marriage during young men's career-development process. Demography, 40(1), 127-149, doi:10.2307/3180815.

Perelli-Harris, B., Kreyenfeld, M., Sigle-Rushton, W., Keizer, R., Lappegard, T., Jasilioniene, A., et al. (2012). Changes in union status during the transition to parenthood in eleven European countries, 1970s to early 2000s. Population Studies, 66(2), 167-182, doi:10.1080/00324728.2012.673004.

Perelli-Harris, B., \& Sánchez Gassen, N. (2012). How similar are cohabitation and marriage? Legal approaches to cohabitation across Western Europe. Population and Development Review, 38, 435-467, doi:10.1111/j.1728-4457.2012.00511.x.

Perelli-Harris, B., Sigle-Rushton, W., Kreyenfeld, M., Lappegard, T., Keizer, R., \& Berghammer, C. (2010). The educational gradient of childbearing within cohabitation in Europe. Population and Development Review, 36(4), 775-801, doi:10.1111/j.17284457.2010.00357.x.

Philipov, D., Speder, Z., \& Billari, F. C. (2006). Soon, later, or ever? The impact of anomie and social capital on fertility intentions in Bulgaria (2002) and Hungary (2001). Population Studies, 60(3), 289-308.

Potancokova, M., Vano, B., Pilinská, V., \& Jurcova, D. (2008). Slovakia: Fertility between tradition and modernity. Demographic Research, 19(25), 973-1018, doi:10.4054/DemRes.2008.19.25.

Prinz, C. (1995). Cohabiting, married or single: Portraying, analyzing and modeling new living arrangements in the changing societies of Europe. Brookfield, VT: Ashgate. 
Rindfuss, R. R., \& Vandenheuvel, A. (1990). Cohabitation - a precursor to marriage or an alternative to being single. Population and Development Review, 16(4), 703-726, doi:10.2307/1972963.

Seltzer, J. A. (2004). Cohabitation in the United States and Britain: Demography, kinship, and the future. Journal of Marriage and Family, 66(4), 921-928, doi:10.1111/j.00222445.2004.00062.x.

Sobotka, T. (2003). Re-emerging diversity: Rapid fertility changes in Central and Eastern Europe after the collapse of the communist regimes. Population and Development Review, 58(45), 451-486.

Sobotka, T., \& Toulemon, L. (2008). Changing family and partnership behaviour: Common trends and persistent diversity across Europe. Demographic Research, 19, 85-138, doi:10.4054/DemRes.2008.19.6.

Soons, J. P. M., \& Kalmijn, M. (2009). Is marriage more than cohabitation? Well-being differences in 30 European countries. Journal of Marriage and Family, 71(5), 11411157.

Spéder, Z., \& Kamarás, F. (2008). Hungary: Secular fertility decline with distinct period effects. Demographic Research, 19(18), 599-664, doi:10.4054/DemRes.2008.19.18.

Stanley, S. M., Whitton, S. W., \& Markman, H. J. (2004). Maybe I do: Interpersonal commitment and premarital or nonmarital cohabitation. Journal of Family Issues, 25(4), 496-519, doi:10.1177/0192513X03257797.

Surkyn, J. J., \& Lesthaeghe, R. (2004). Value orientation and the second demographic transition (SDT) in Northern, Western and Southern Europe: An update. Demographic Research, 2(3), 47-86, doi:10.4054/DemRes.2004.S3.3.

Théry, I. (1998). Couple, filiation et parenté aujourd'hui. Paris: Odile Jacob et La Documentation Francaise.

Thornton, A. (2005). Reading history sideways: The fallacy and enduring impact of the developmental paradigm on family life. Chicago: University of Chicago Press.

Thornton, A., Axinn, W. G., \& Xie, Y. (2007). Marriage and cohabitation. Chicago: Chicago University Press.

Thornton, A., \& Philipov, D. (2009). Sweeping changes in marriage, cohabitation, and childbearing in Central and Eastern Europe: New insights from the Developmental Idealism framework. European Journal of Population, 25(2), 123-156, doi:10.1007/s10680-009-9181-2.

Thornton, A., \& Young-DeMarco, L. (2001). Four decades of trends in attitudes toward family issues in the United States: The 1960s through the 1990s. Journal of Marriage and Family, 63(4), 1009-1037.

Trost, J. (1978). Renewed social institution - nonmarital cohabitation. Acta Sociologica, 21(4), 303-315.

van de Kaa, D. J. (1987). Europe's Second Demographic Transition. Population Bulletin, 42(1).

van de Kaa, D. J. (2001). Postmodern fertility preferences: From changing value orientation to new behavior. Population and Development Review, 27, 290-331.

Vikat, A., Spéder, Z., Beets, G., Billari, F. C., Bühler, C., Désesquelles, A., et al. (2007). Generation and Gender Survey: Towards a better understanding of relationships and processes in the life course. Demographic Research, 17, 389-440 doi:10.4054/DemRes.2007.17.14. 
Villeneuve-Gokalp, C. (1991). From marriage to informal union: recent changes in the behavior of French couples. Population, 3, 81-111.

Wiik, K. A. (2009). You'd better wait. Socio-economic background and timing of first marriage versus first cohabitation. European Sociological Review, 25(2), 139-153, doi:10.1093/esr/jcn045,.

Wiik, K. A., Bernhardt, E., \& Noack, T. (2009). A study of commitment and relationship quality in Sweden and Norway. Journal of Marriage and Family, 71(3), 465-477, doi:10.1111/j.1741-3737.2009.00613.x.

Wiik, K. A., Bernhardt, E., \& Noack, T. (2010). Love or money? Marriage intentions among young cohabitors in Norway and Sweden. Acta Sociologica, 53(3), 269-287.

Willoughby, B. J., Carroll, J. S., \& Busby, D. M. (2012). The different effects of "living together": Determining and comparing types of cohabiting couples. Journal of Social and Personal Relationships, 29(3), 397-419, doi:10.1177/0265407511431184. 
TABLE 1. PERCENT (WEIGHTED) DISTRIBUTION OF KEY INDICATORS DEFINING DIFFERENT MEANINGS OF COHABITATION, BY COUNTRY $(\mathrm{N}=9,113)$

\begin{tabular}{|c|c|c|c|c|c|c|c|c|c|c|}
\hline & \multicolumn{4}{|c|}{ Western and Northern Europe } & \multicolumn{6}{|c|}{ Central and Eastern Europe } \\
\hline & Austria* & Germany & France & Norway & Bulgaria & Georgia & Hungary & Lithuania & Romania & Russia \\
\hline Marital intentions 3 years & 47.5 & 33.2 & 37.1 & 17.3 & 42.8 & 79.7 & 52.1 & 61.8 & 74.1 & 47.2 \\
\hline Marriage is not outdated & 43.4 & 48.8 & 50.9 & 40.7 & 27.3 & 82.2 & 40.6 & 33.6 & 49.4 & 52.6 \\
\hline Marriage is outdated & 25.5 & 27.0 & 26.8 & 22.3 & 48.1 & 9.3 & 32.2 & 29.7 & 17.5 & 24.3 \\
\hline Undecided & 31.2 & 24.2 & 22.3 & 37.0 & 24.6 & 8.5 & 27.6 & 36.7 & 33.1 & 23.2 \\
\hline Economically deprived & 6.0 & 13.2 & 25.3 & 2.7 & 74.2 & 58.7 & 19.0 & 15.1 & 42.6 & 50.9 \\
\hline Total $n$ & 879 & 748 & 1,173 & 1,571 & 840 & 906 & 1,148 & 562 & 449 & 837 \\
\hline
\end{tabular}

Note: Table includes weighted percentages and unweighted number of cases *different age range (18-45) 
TABLE 2. AN EMPIRICAL TYPOLOGY OF DIFFERENT MEANINGS OF COHABITATION BASED ON THREE INDICATORS

$\begin{array}{lll}\text { intends to marry } & \text { agrees that marriage } & \text { has trouble making } \\ \text { within three years } & \text { is outdated } & \text { ends meet }\end{array}$

\begin{tabular}{lccl}
\hline Prelude to marriage & yes & no & not used $^{1}$ \\
Trial marriage & no & no & no \\
Economic reasons & no & no & yes \\
Conformist & yes & no & not used $^{1}$ \\
Refusal of marriage & no & yes & not used $^{1}$ \\
Marriage is irrelevant & no & neutral & not used $^{1}$ \\
\hline
\end{tabular}

Note: ${ }^{1}$ this indicator is not used to classify respondents in that type of cohabitation 
TABLE 1. PERCENT (WEIGHTED) DISTRIBUTION OF DIFFERENT MEANINGS OF COHABITATION, MEASURE OF VARIATION (ENTROPY), BY COUNTRY $(\mathrm{N}=9,113)$

\begin{tabular}{|c|c|c|c|c|c|c|c|c|c|c|}
\hline & \multicolumn{4}{|c|}{ Western and Northern Europe } & \multicolumn{6}{|c|}{ Central and Eastern Europe } \\
\hline & Austria* & Germany & France & Norway & Bulgaria & Georgia & Hungary & Lithuania & Romania & Russia \\
\hline Prelude to marriage & 27.0 & 20.2 & 24.8 & 10.5 & 16.0 & 66.0 & 24.2 & 23.2 & 39.0 & 25.9 \\
\hline Trial marriage & 15.2 & 26.4 & 19.3 & 29.3 & 1.7 & 5.7 & 13.4 & 8.1 & 5.2 & 9.8 \\
\hline Economic reasons & 1.2 & 2.2 & 6.8 & 0.9 & 9.6 & 10.5 & 2.6 & 2.4 & 5.2 & 16.9 \\
\hline Conformist & 20.5 & 13.0 & 12.3 & 6.9 & 26.8 & 13.7 & 27.9 & 38.7 & 35.0 & 21.3 \\
\hline Refusal of marriage & 17.9 & 21.0 & 21.5 & 20.5 & 32.3 & 2.1 & 19.3 & 13.6 & 4.8 & 14.5 \\
\hline Marriage is irrelevant & 18.3 & 17.1 & 15.4 & 31.9 & 13.7 & 1.9 & 12.7 & 14.2 & 10.7 & 11.6 \\
\hline $\begin{array}{l}\text { Proportion cohabiting of all } \\
\text { resident unions }\end{array}$ & 30.2 & 12.2 & 19.7 & 23.0 & 10.8 & 14.2 & 13.6 & 11.4 & 5.3 & 15.4 \\
\hline $\begin{array}{l}\text { Measure of variation of } \\
\text { cohabitation types (entropy) }\end{array}$ & 0.74 & 0.76 & 0.76 & 0.71 & 0.67 & 0.45 & 0.72 & 0.68 & 0.6 & 0.73 \\
\hline Total N & 879 & 748 & 1,173 & 1,571 & 840 & 906 & 1,148 & 562 & 449 & 837 \\
\hline
\end{tabular}

Note: Table includes weighted percentages and unweighted number of cases *different age range (18-45 years) 